\title{
EDITORIAL
}

\section{Measurements of dyspnoea during bronchoconstriction}

\author{
K.J. Killian
}

The perception of bronchoconstriction is clinically important. This is because detection, recognition and rating of the severity of bronchoconstriction allows patients to selfmedicate and seek help. Reliable interpretation of bronchoconstriction may lead to appropriate treatment whereas unreliable perception may lead to inappropriate treatment. Failure to recognize the severity of bronchoconstriction leads to life-threatening episodes.

Under ideal experimental conditions, an added resistance equivalent to $20 \%$ of the background resistance evokes detection on $50 \%$ of occasions in normal subjects and patients with airflow obstruction [1-3]. Inappropriateness between tension and displacement arises because the resistance or elastance opposing inspiratory muscle contraction increases modestly $[1,4]$. When inspiratory contraction is impeded to a greater extent, intense activation of the Golgi tendon organs is perceived as a sense of tension $[5,6]$. Muscle shortening leads to a sense of displacement which is consciously appreciated in terms of its achieved effects [7, 8]. During breathing, the activation of the muscle spindles, chest wall joint receptors and intrapulmonary stretch receptors are collectively responsible for the sensations of volume, flow rate and ventilation [9]. The conscious awareness of the intensity of the motor command generates a sense of effort $[10$, 11]. The sense of effort intensifies over time as the muscle fatigues $[12,13]$ and more effort is required to drive weak muscles [14]. A sense of weakness is generated whenever effort is excessive relative to achievement. The relationship between effort, tension and displacement depends on the forces opposing contraction, the strength of the muscle and the evolution of fatigue $[15,16]$. Effort intensifies with the velocity and extent of displacement when the forces opposing contraction are increased. Effort intensifies with tension when the forces opposing contraction are substantial. These sensations are easily confused.

Perceptions also arise in relationship to the control of breathing where underbreathing leads to air hunger and overbreathing leads to a less distinct discomfort [17-22]. These perceptual features are common to hunger, thirst and thermal comfort (satiation). Intrapulmonary receptor stimulation gives rise to visceral sensations. Tracheal irritation and discomfort is well appreciated. Other visceral sensations are not well characterized.

Correspondence: K.J. Killian, Ambrose Cardiorespiratory Unit, McMaster University Medical Center, 1200 Main Street West, Hamilton, Ontario, L8N 3Z5, Canada. Fax: 19055215053.
The conscious awareness of bronchoconstriction is expressed through the intensities and the relationships between effort, tension, displacement, perceptions related to the control of breathing and visceral sensations. With bronchoconstriction, airways narrow and gas is trapped in the lungs. Hyperinflation causes the actin and myosin filaments to overlap in the shortened inspiratory muscles. More effort is required to drive the shortened and weakened muscles to overcome the resistive and elastic forces opposing inspiratory muscle contraction [23-26]. Exertional discomfort intensifies in a positive accelerating manner with the motor command. The inability of the inspiratory muscles to shorten until any positive end-expiratory pressure (PEEP) is exceeded may be appreciated as a sense of mechanical dissociation [27]. Following repeated episodes of bronchoconstriction, facilitation of synaptic transmission through association pathways generates complex perceptual experiences, which may be characteristic of the overall experience. The sense of tightness may be such a sensory experience. The discomfort is largely confined to the inspiratory muscles. The force required to generate effective expiratory flow is modest and the capacity of the expiratory muscles to generate force is not compromised.

Bronchoconstriction leads to the continued perfusion of poorly-ventilated lung units causing hypoxaemia. Extreme bronchoconstriction may cause ventilatory failure with hypercapnia and acidaemia. Breathlessness and air hunger may be experienced when the control of arterial blood gases is challenged [28].

Variability in the symptom response during bronchoconstriction is confusing. In 1973, McFADDEN et al. [29] reported that "breathlessness at rest" receded in 22 hospitalized asthmatic patients, when visible contraction of the sternocleidomastoid muscles disappeared. Substantial impairments in spirometry, resistance and lung volume (hyperinflation) remained in the now asymptomatic patients. In 1976, RUBINFELD and PAIN [30] reported that "just noticeable symptoms" were found with variable impairments in spirometry, gas trapping and hyperinflation in naturally occurring asthma and during induced bronchoconstriction. In 1982, BURDON et al. [31] quantified the intensity of dyspnoea (Borg 0-10 scale) during acute histamine-induced bronchoconstriction in 45 asthmatics. "Just noticeable" dyspnoea was experienced prior to any measurable decline in the forced expiratory volume in one second (FEV1) and "moderate" dyspnoea (3 on the Borg scale) was experienced following a $20 \%$ reduction in the FEV1. Substantial variability in intensity was noted from subject to subject. However, subjects with 
airflow obstruction at baseline and the more reactive subjects, with the lowest provocative concentration causing a $20 \%$ fall in FEV1 (PC20) had blunted perceptual responses and contributed significantly to this variability. In 1993, 10 of 120 asthmatics experienced no dyspnoea following a $20 \%$ reduction in the measured FEV1 during methacholine-induced bronchoconstriction (poor perception); the intensity of dyspnoea during exercise was normal in these subjects [32]. One can conclude that dyspnoea intensifies systematically as the FEV1 falls, the intensity of dyspnoea varies from subject to subject, increased airway responsiveness and persistent airflow obstruction blunt the perceptual response to bronchoconstriction and no dyspnoea is experienced by $\sim 10 \%$ of asthmatics following a $20 \%$ reduction in the measured FEV1. Adaptation is currently the only recognized factor contributing to the variability in the intensity of dyspnoea during bronchoconstriction. The loss of asthma control with the development of persistent airflow obstruction or frequent episodes of bronchoconstriction will result in adaptation and will convert good perception into poor perception. Reliance on symptoms alone is particularly detrimental in the most compromised asthmatics. The variable relationship between symptoms and the severity of bronchoconstriction creates a continued need for the monitoring of pulmonary function.

In this issue, we are presented with a psychophysical study conducted on 134 asthmatics by BIJL-HofLAND et al. [33]. Each individual estimated the perceived intensity of dyspnoea using a Visual Analogue Scale (VAS) following doubling concentration of histamine up to $16 \mathrm{mg} \cdot \mathrm{mL}^{-1}$ or a $20 \%$ reduction in FEV1. The goal was to isolate parameters that would allow discrimination between good and poor perception. The perceived magnitude of dyspnoea was matched to $35 \mathrm{~mm}$ on a $100 \mathrm{~mm}$ line following a $20 \%$ reduction in the baseline FEV1. The intraquartile range (IQR) was 21-52 $\mathrm{mm}$. The slope of the response was $1.05 \mathrm{~mm}$ for each percentage drop in the baseline FEV1; the IQR was from 0.59-1.49. These parameters are analogous to the $\mathrm{PC} 20$ and the drop in the FEV1 relative to the increase in methacholine.

Direct magnitude scaling requires matching the perceived severity of asthma symptoms to numbers, descriptive phrases and line lengths during induced bronchoconstriction. Sensory rating scales began in the last century using units of just noticeable differences (JND). There is a well known linear relationship when the number of JNDs are plotted against the logarithmic transformation of stimulus magnitude (Weber-Fechner law) [34, 35]. However, it is not broadly appreciated that the absolute perceptual magnitude associated with each JND systematically increases from the absolute threshold. Each JND is not equal in perceptual magnitude and it is an ordinal scale.

S.S. Stevens noted that the fundamental nature of all measurements is the matching of one continuum to another continuum. These matches require preset rules (ordinal, interval or ratio). Failure to set the rules and violations of permissible transformations were common practice. The addition of the small constant to permit logarithmic transformation of the zero ratings in the study reported in this issue is a violation of a ratio scale. Furthermore, the statistical handling of the data often violated mathematical rules [36]. Validity required that the preset rules were obeyed in addition to the demonstration of reproducibility and responsiveness. S.S. Stevens invented the ratio scaling technique called open magnitude scaling. Numbers were chosen by the subject to match the magnitude of sensory stimuli which usually spanned the entire stimulus range. The preset rule was that the ratio change in the number domain must reflect the ratio change in the perceptual domain. The relationship proved to be a power function $\left(\psi=\kappa \times \theta^{\mathrm{n}}\right)$; for any given ratio change in the stimulus magnitude $(\theta)$ there was a ratio change in the perceived magnitude $(\psi)$. The ratios remained constant throughout the entire range as depicted by the constant exponent (n). Low exponents were found where the dynamic range of stimulation was very wide (i.e. sound and light intensity $\mathrm{n}<0.4$ ). High exponents were found where the dynamic range of stimulation was narrow (i.e. perceived exertion $n=1.7)$. To demonstrate validity S.S. Stevens showed that magnitude estimation gave similar exponents to those found with magnitude production. Any continuum could be used to match the perceived magnitude (cross-modality matching). However, one could predict the exponent found with other matching continua based on their known exponents. S.S. Stevens called this transitivity, which was an extremely critical test of validity. Considerable excitement was generated by the new psychophysical law.

With time, it became clear that the derived exponents changed with the context of the experimental study. The range of stimulation, duration of the stimulus and the state of adaptation of the sensory system caused changes in the perceived response. The psychophysical law appeared to be context-dependent. Poulton [36] was particularly instrumental in highlighting the various biases in open magnitude scaling. Comparison of sensory magnitude across individual subjects proved increasingly difficult. Standard stimulus magnitudes were established with given numbers to provide equalization between the numbers used by individuals. These modal stimuli produced distortions in the derived exponents violating the principles of validity. Equalization of the sum total of each individual estimates by multiplying the numbers chosen by a constant to ensure the same total scores did not overcome the difficulties of comparison across individuals. There was no inherent certainty that the same stimulus was perceived equally by all subjects. Open magnitude scaling had its greatest utility in the study of populations and was particularly useful in the study of changing parameters of stimulation within the same subjects. Comparison of absolute magnitude across subjects was considerably more difficult.

Category scales had been pragmatically used as a way to compare absolute magnitude across individuals for centuries without any theoretical basis. The limited number of categories was seen as a problem. The VAS was constructed to overcome this limitation in that it provided an infinite number of categories. The logarithmic transformation of the VAS proved to be linearly related to the logarithmic transformation of the stimulus magnitude. However, the derived exponent was systematically less than the exponent found using open magnitude scaling [38]. Theoretical problems were identified [39]. For the same stimulus magnitudes, open magnitude ratings were not linearly related to the VAS magnitude ratings. Validity was violated [40]. S.S. Stevens equated the judgement process associated with the use of the VAS as a partition 
process which lies between discrimination scaling and ratio scaling.

BorG [41] grappled with the validity of open magnitude scaling and the simplicity of quantitative semantic scaling using descriptive categories. The descriptive phrases carry a meaning which is immediately obvious ("quantitative semantics"). The stimulus range and the perceptual range are pragmatically fixed and G.A.V. Borg felt that it must be possible to generate a scale that yielded the exponent found with open magnitude scaling using a category scale with tagged numbers. BoRG [41] pragmatically studied the ratio relationships between common phrases describing magnitude and tagged the numbers between zero and 10 such that the exponent using open magnitude scaling would result. The net result was an absolute scale with ratio properties. The Borg scale has proved remarkably rugged, and simple to use, is readily understood by people of widely different educational and ethnic backgrounds and the scale values can be used in the same manner as any other physiological measurement [42].

Visual Analogue Score rating scales and Borg rating scales are now both widely used. S.S. Stevens assault on the validity of these scales has not deterred the use of either scale. The argument can be reduced to simple criteria. Following an acute $20 \%$ reduction in the baseline forced expiratory volume in one second, the intensity of dyspnoea is $35 \mathrm{~mm}$ on a $100 \mathrm{~mm}$ Visual Analogue Scale score, "moderate" 3 on the Borg scale and an infinite range of numbers using open magnitude scaling. The Borg scale allows a crude estimate of absolute magnitude using quantitative semantics while the numbers give an estimate of the ratio. Whether this is true on the Visual Analogue Score scale remains contentious. Absolute validity is unlikely to be achieved by either scale. Quantitative semantics has existed and served a useful role for all of the human history. One might forward the adage "keep it simple". Any measurement is only as good as it is useful, and scaling techniques can be useful even if they are not strictly valid.

\section{References}

1. Bennett ED, Jayson MIV, Rubenstein D, Campbell EJM. The ability of man to detect added non-elastic loads to breathing. Clin Sci 1962; 23: 155-162.

2. Wiley RL, Zechman FW Jr. Perception of added airflow resistance in humans. Respir Physiol 1967; 2: 73-87.

3. Burki NK, Mitchell K, Chaudhary BA, Zechman FW. The ability of asthmatics to detect added resistive loads. Am Rev Respir Dis 1978; 117: 71-75.

4. Campbell EJM, Freedman S, Smith PS, Taylor ME. The ability of man to detect added elastic loads to breathing. Clin Sci 1961; 20: 223-231.

5. Bakers JHCM, Tenney SM. Perception of some sensations associated with breathing. Respir Physiol 1970; 10: 85-92.

6. Stubbing DG, Ramsdale EH, Killian KJ, Campbell EJM. Psychophysics of inspiratory muscle force. $J$ Appl Physiol 1983; 54: 1216-1221.

7. Goodwin GM, McCloskey DI, Matthews PBC. The contribution of muscle afferents to kinaesthesia shown by vibration induced illusions of movement and by the effects of paralysing joint afferents. Brain 1972; 95: 705748.
8. Matthews PBC. Muscle afferents and kinesthesia. $\mathrm{Br}$ Med Bull 1977; 33: 137-142.

9. Stubbing DG, Killian KJ, Campbell EJM. The quantification of respiratory sensations by normal subjects. Respir Physiol 1981; 44: 251-260.

10. McCloskey DI. Kinesthetic sensibility. Physiol Rev 1978; 58: 763-820.

11. Matthews PBC. Where does Sherringtons "muscular sen$\mathrm{se}^{\prime}$ originate? Muscles, joints, corollary discharges? Ann Rev Neurosci 1982; 5: 189-218.

12. Kearon MC, Summers E, Jones NL, Campbell EJM, Killian KJ. Breathing during prolonged exercise in man. $J$ Physiol 1991; 442: 477-487.

13. Kearon MC, Summers E, Jones NL, Campbell EJM, Killian KJ. Effort and dyspnoea during work of varying intensity and duration. Eur Respir J 1991; 4: 917-925.

14. Hamilton AL, Killian KJ, Summers E, Jones NL. Muscle strength, symptom intensity, and exercise capacity in patients with cardiorespiratory disorders. Am J Respir Crit Care Med 1995; 152: 2021-2031.

15. Killian KJ, Campbell EJM. Dyspnoea. In: Crystal RG, West JB, Barnes PJ, Weibel ER, eds. The Lung: Scientific Foundations. 2nd Edn. Philadelphia, Lippincott-Raven, 1997; pp. 1865-1881.

16. Killian KJ, Campbell EJM. Dyspnea. In: Roussos C, eds. The Thorax. 2nd Edn. New York, Marcel Dekker, Inc., 1995; pp. 1709-1747.

17. Banzett RB, Lansing RW, Reid MB, Adams L, Brown R. "Air hunger" arising from increased $\mathrm{PCO}_{2}$ in mechanically ventilated quadriplegics. Respir Physiol 1989; 76: 53-68.

18. Banzett RB, Lansing RW, Brown R, et al. "Air Hunger" from increased $\mathrm{PCO}_{2}$ persists after complete neuromuscular block in humans. Respir Physiol 1990; 81: 1-18.

19. Gandevia SC, Killian KJ, McKenzie DK, et al. Respiratory sensations, cardiovascular control, kinaesthesia and transcranial stimulation during paralysis in humans. $J$ Physiol (Lond) 1993; 470: 85-107.

20. Chonan T, Mulholland MB, Altose MD, Cherniack NS. Effects of changes in level and pattern of breathing on the sensation of dyspnea. J Appl Physiol 1990; 69: 12901295.

21. Chonan T, Mulholland MB, Cherniack NS, Altose MD. Effects of voluntary constraining of thoracic displacement during hypercapnia. J Appl Physiol 1987; 63: 1822-1828.

22. Schwartzstein RM, Simon PM, Weiss JW, Fencl V, Weinberger SE. Breathlessness induced by dissociation between ventilation and chemical drive. Am Rev Respir Dis 1989; 139: 1231-1237.

23. Hamielec CM, Summers E, O'Byrne PM, et al. Factors contributing to breathlessness during asthma. Am Rev Respir Dis 1988; 137: 242 (Abstract).

24. O'Donnell DE, Sanii R, Giesbrecht G, Younes M. Effect of continuous positive airway pressure on respiratory sensation in patients with chronic obstructive pulmonary disease during submaximal exercise. Am Rev Respir Dis 1988; 138: 1185-1191.

25. O'Donnell DE, Sanii R, Younes M. Improvement in exercise endurance in patients with chronic airflow limitation using continuous positive airway pressure. Am Rev Respir Dis 1988; 138: 1510-1514.

26. Bellofiore S, Ricciardolo FLM, Ciancio N, et al. Changes in respiratory drive account for the magnitude of dyspnoea during bronchoconstriction in asthmatics. Eur Respir $J$ 1996; 9: 1155-1159.

27. O'Donnell DE, Webb KA. Exertional breathlessness in patients with chronic airflow limitation: the role of lung 
hyperinflation. Am Rev Respir Dis 1993; 148: 13511357.

28. Schwartzstein RM, Christiano LM. Qualities of respiratory sensation. In: Lenfant C, eds. Respiratory Sensation. New York, Marcel Dekker, Inc., 1996; pp. 125-154.

29. McFadden ER Jr, Kiser R, deGroot WJ. Acute bronchial asthma. Relations between clinical and physiologic manifestations. N Engl J Med 1973; 288: 221-225.

30. Rubinfeld AR, Pain MCF. Perception of asthma. Lancet 1976; 24: 882-884.

31. Burdon JGW, Juniper EF, Killian KJ, Hargreave FE, Campbell EJM. Perception of breathlessness in asthma. Am Rev Respir Dis 1982; 126: 825-828.

32. Killian KJ, Summers E, Watson RM, O'Byrne PM, Jones NL, Campbell EJM. Factors contributing to dyspnea during bronchoconstriction and exercise in asthmatic subjects. Eur Respir J 1993; 6: 1004-1010.

33. Bijl-Hofland ID, Cloosterman SGM, Folgering HThM, Akkermans RP, van den Hoogen $\mathrm{H}$, van Schaych $\mathrm{CP}$. Measuring breathlessness during histamine challenge: a simple standardized procedure in asthmatic patients. Eur Respir J 1999; 13: 955-960.

34. Weber EH. The Sense of Touch. New York, Academic Press, 1978.
35. Fechner GT. Elemente der Psychophysik. Leipzig, Breitkopf und Hartel, 1860.

36. Stevens SS, ed. Mathematics, measurement, and psychophysics. In: Handbook of Experimental Psychology. New York, Wiley, 1951; pp. 1-49.

37. Poulton EC. Biases in quantitative judgements. Appl Ergonom 1982; 13: 31-42.

38. Stevens SS. Problems and methods of psychophysics. Psychol Bull 1958; S5: 177-196.

39. Stevens SS. Partition scales and paradoxes. In: Stevens G, ed. Psychophysics. New York, Wiley, 1975; pp. 134171.

40. Stevens SS, Galanter EH. Ratio scales and category scales for a dozen perceptual continua. J Exp Psychol 1957; 54: 377-411.

41. Borg GAV. A category scale with ratio properties for intermodal and interindividual comparisons. In: Geissler HG, Petzold P, eds. Psychophysical Judgment and the Process of Perception. Proceedings of the 22nd International Congress of Psychology. Amsterdam, North Holland Publishing Co., 1980; pp. 25-34.

42. Killian KJ, Summers E, Jones NL, Campbell EJM. Dyspnea and leg effort during incremental cycle ergometry. Am Rev Respir Dis 1992; 145: 1339-1345. 